\title{
Mesa Redonda
}

(1.........

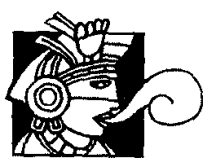

\section{A ochenta años de la Escuela de Verano}

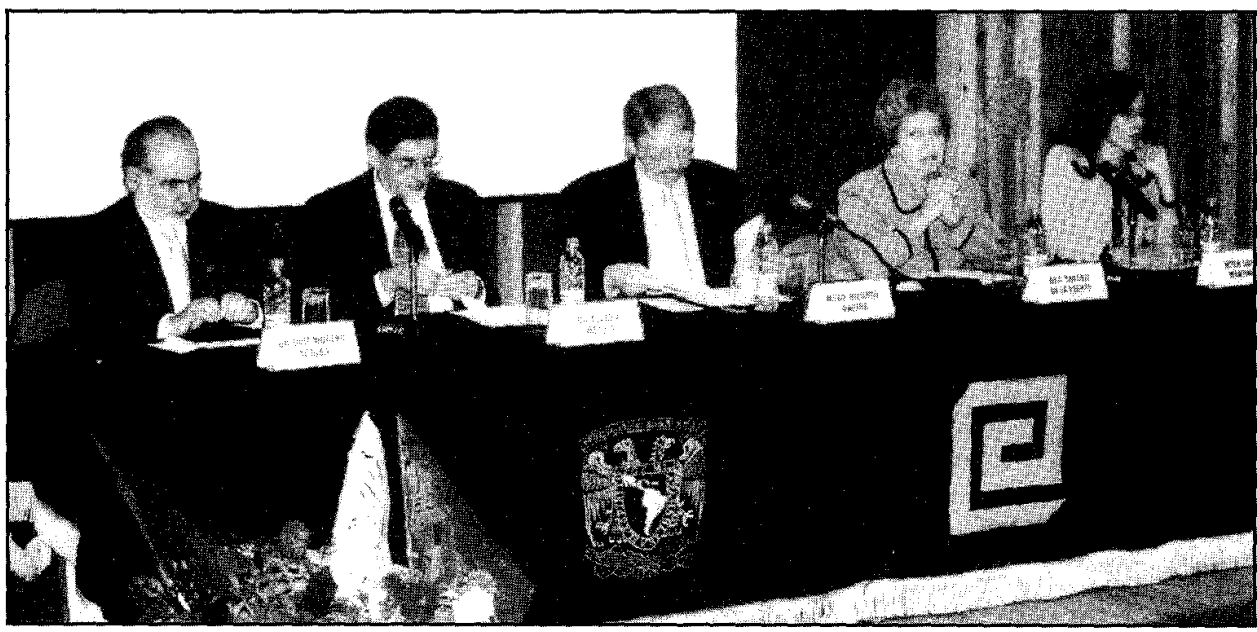

Dr. José Moreno de Alba, Dr. Álvaro Matute, Mtro. Ricardo Ancira, Dra. Beatriz de la Fuente y Mtra. Sara Martínez

14 de septiembre de 2001

Auditorio José Vasconcelos 



\section{A ochenta años de la Escuela de Verano}

Dr. Guillermo Pulido González



oy para nosotros es un día muy significativo, porque con esta mesa redonda $A$ ochenta años de la Escuela de Verano, pretendemos hacer un breve recuento de lo que es este Centro después de ocho décadas de vida académica y analizar las amplias perspectivas que se abren para su quehacer en el futuro. ¿Quiénes más indicados para realizar esta reflexión que las distinguidas personalidades que hoy nos acompañan en esta mesa? Todos sabemos que ellos desde las aulas, la dirección, los cubículos de investigación, el trabajo de campo, en el extranjero, han signado el destino de este nuestro CEPE.

Para nuestra comunidad académica, es motivo de gran alegría reunir en esta mesa redonda a tan destacados universitarios que han aportado su talento, su vocación de servicio y su integridad para el engrandecimiento de la Universidad Nacional Autónoma de México y el cumplimiento de nuestra misión que es: "Universalizar el conocimiento sobre la lengua española y la cultura mexicana, proyectando la presencia de la UNAM en el contexto internacional".

Me es muy grato dar la bienvenida a los participantes de la mesa, con quienes esta Escuela siempre estará en deuda, y no me queda más que agradecer profundamente, en nombre de la comunidad y en el mío propio, que nos honren hoy con su presencia.

Cedo la palabra a la Doctora Olga Elizabeth Hansberg, quien atinadamente dirige la Coordinación de Humanidades, agradeciéndole especialmente que haya distinguido al CEPE, aceptando inaugurar este magno evento académico que hoy nos reúne con motivo del octogésimo aniversario del Centro de Enseñanza para Extranjeros.

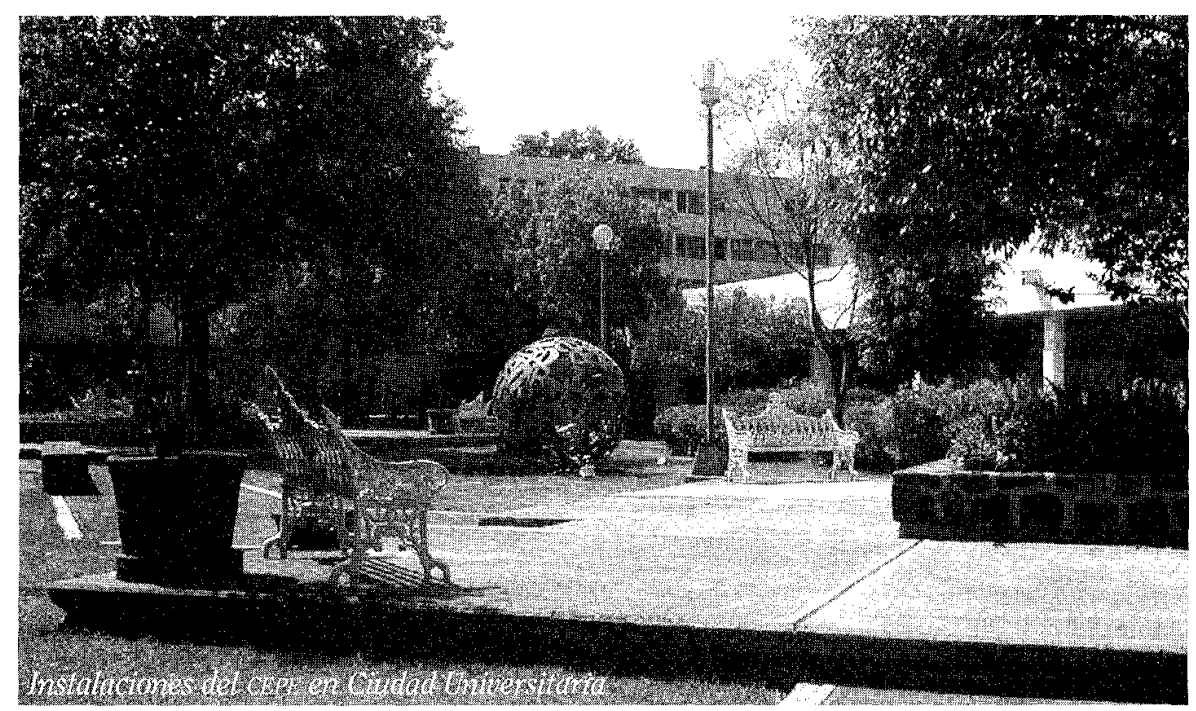

